\title{
A Rhetorical Approach to the Literary Essay: Pedagogical Implications
}

\author{
Margarita Esther Sánchez Cuervo \\ Universidad de Las Palmas de Gran Canaria \\ margaritaesther.sanchez@ulpgc.es
}

\begin{abstract}
The teaching of the literary essay is usually ignored in many universities due to its probing and inconclusive form which has not favoured the existence of models of analysis. However, the argumentative nature of this discourse can be examined through a reading that allows the recognition of some rhetorical operations like the invention of arguments (inuentio), their arrangement (dispositio) and expressive manifestation (elocutio). This article proposes a model of analysis following this rhetorical approach. In particular, I apply this analysis to a short essay by Virginia Woolf, 'Royalty'. Woolf has been considered a major writer of the twentieth century. Although the style of her novels has been extensively researched from diverse perspectives, the style of her essays has not received much critical attention. Throughout my study, I indicate how the recognition and interpretation of arguments and rhetorical figures can help to define the style of this essay. Furthermore, I provide some guidelines for the identification and further interpretation of these rhetorical elements. Both the analysis and the guidelines can be useful in the literature and composition classes.
\end{abstract}

Keywords: teaching literature, literary essay, argumentative discourse, rhetorical figures, Virginia Woolf 


\section{Introduction}

The teaching of literature in many universities is usually restricted to the major literary genres: narrative, poetry and drama. As a result, the essay has often been neglected in contemporary literature teaching programmes. ${ }^{1}$ The literary essay has been traditionally considered a hybrid genre that comprises different types of genre such as the expository, the descriptive, the narrative and the argumentative. The essay presents an exploratory, experiential and inconclusive form that has restrained the existence of precise models of analysis and, for this reason, the teaching of the essay as a genre is not very common. In this respect, Saloman (2012: 13) states that the absence of the literary essay in the classroom is due to the indifference that many scholars feel towards this genre, and the fact that they aren't able to recognise either its literary value or its significance to modern writers. Furthermore, the openness of this genre has favoured the writers' autonomy and the reader's participation in the essayistic process, which has encouraged the existence of diverse interpretive responses (Saloman, 2013: 56). Although it is a genre that is difficult to categorise, the argumentative nature of the essayistic act is usually preponderant and the essay can be then approached following a rhetorical model of analysis.

In this study I propose a model of analysis based on Virginia Woolf's essay 'Royalty'. In order to carry out the study of this text, it is advisable that students are familiar with Woolf's context of production of her non-fiction work. As an essayist, Woolf is renowned for her feminist stance, her ideas about literature in general and the essay in particular and, in many cases, her essays are also a pretext for acquiring a better understanding of her novels. ${ }^{2}$

Apart from her long celebrated essays A Room of One's Own, which is mainly concerned with the relations between women and fiction throughout history, and Three Guineas, which deals with political issues on the verge of the second world war, she wrote hundreds of shorter essays for the press in which she reviewed the works of both famous and little known women writers. As a literary reviewer, Woolf reformulates the traditional definition of the essay as an 'expository' genre and rejects her contemporaries' conception of the critic as a privileged reader that should judge one's critical work as an objective science. Instead, the essay represents for Woolf "the expression of personal opinion" (Woolf, 1992: 6), and an aesthetic end in itself that should possess a flexible form capable of holding every aspect of human experience (Lojo, 2001: 78). These Woolf's shorter essays can be read following a rhetorical model of analysis. Through this model, some principles related to the invention of arguments (inuentio), their arrangement (dispositio) and expressive manifestation (elocutio) are useful in the construction of argumentative texts like the modern essay (Arenas, 1997: 134).

The following section of this article discusses the essay within a rhetorical context and offers an outline of the rhetorical levels encountered in Woolf's essay: inuentio, dispositio and elocutio. After this explanation I apply the rhetorical model to her essay 'Royalty'. In the last section of this study I try to point out how the account of arguments and figures found can help to define the style of 'Royalty', and I offer some 
guidelines for the identification of these elements in Woolf's and other authors' essays (Sánchez Cuervo, fc.).

\section{Theoretical framework: the essay from a rhetorical perspective}

Before conducting the analysis, it is necessary to possess some knowledge about the rhetorical tradition as regards to its historical background and more modern conceptions of this discipline. Although students are used to recognising and evaluating the rhetorical figures that are present in poetic texts, it is uncertain whether they have acquired the operations of classical rhetoric that are an essential part of the production of rhetorical speech, and that will be pointed out in the analysis of the essay.

In his Rhetoric, Aristotle refers to a semantic and pragmatic conception of logos immersed in a construction of the speaker, the spoken content and the hearer (Aristotle 1909: I.3). In a wide sense, Rhetoric is at the same time a general model for the production of texts and an instrument of textual analysis (Albadalejo 1989: 11; Lausberg 1983: 83-84). The textual model of Rhetoric thus possesses a semiotic nature that includes the formal construction of the text (syntax) deriving from its referential elements (semantics) and that confers a relevant place to all intervening elements in the communication of the text (pragmatics): addresser, addressee and the contexts of production and reception. In Woolf's essays, the pragmatic dimension is particularly important because of the explicit presence of the essayist wishing to concur with the "common reader" to whom she dedicates her first published volume of essays. ${ }^{3}$

But Rhetoric also becomes a theory of argumentation such as that devised by Perelman and Olbrechts-Tyteca (1969), who studied both the rational and linguistic mechanisms present in argumentation and the effects of the text upon the audience. In this line, arguments can be defined as linguistic patterns that transfer acceptability from premises to conclusions. Similarly, rhetorical figures can also serve as arguments because of the ways they are constructed to engage the audience thanks to their effective nature and their capacity for attracting attention (Tindale, 2004: 63).

\subsection{Partes artis}

Classical rhetoric recognises five operations or partes artis in the production of rhetorical speech: inuentio, dispositio, elocutio, memoria and actio ([Cicero] 1981: I.7; Quintilian 1920: III.3). In argumentative texts like the essay, the levels of memoria and actio are usually absent since they have to do with the memorisation of the text and its oral reproduction, respectively. The inventive and dispositive levels are represented linguistically by means of the elocutive or verbal manifestation of the text. Through inuentio, the author selects those elements that comprise the referent of discourse and that allows different types of arguments to be chosen and constructed (Crosswhite, 2011: 200-201). In essays like 'Royalty', the central argument is the act/person interaction. With this reasoning, the reaction of the act that corresponds to the person's 
artistic output, judgement, or reaction, is meant to revise our conception of that individual (Perelman and Olbrechts-Tyteca, 1969: 297-98). In this essay, Woolf reviews the queen Marie of Roumania's autobiography. Therefore, the interaction will be made between this monarch and her life story (Fahnestock, 2005: 219-20).

Through dispositio, the syntactic and semantic conceptual elements deriving from inuentio are structured. The partes orationis are located in the dispositio level, which vertebrates the rhetorical organisation of the essay and its referent. The essay, which is a more spontaneous form than the classical rhetorical speech, can be organised into four partes orationis: exordium or introduction, narratio/expositio or narration/exposition, argumentatio or argumentation and epilogue (Barthes, 1982: 66). ${ }^{4}$ The second and third categories in particular contribute to the syntactic organisation of the text. There are two main ways in which the partes orationis can be ordered: the ordo naturalis, which follows the order of the four categories, and the ordo artificialis, which does not. In 'Royalty' an ordo artificialis prevails because narratio does not fulfil its classical function of illustrating some subsequent reasoning but rather merges with the author's observations. As a result, narratio becomes argumentation proper (Sánchez-Cuervo 2004: 265-266; 2010: 269-70).

Figure 1: Diagram of the partes artis

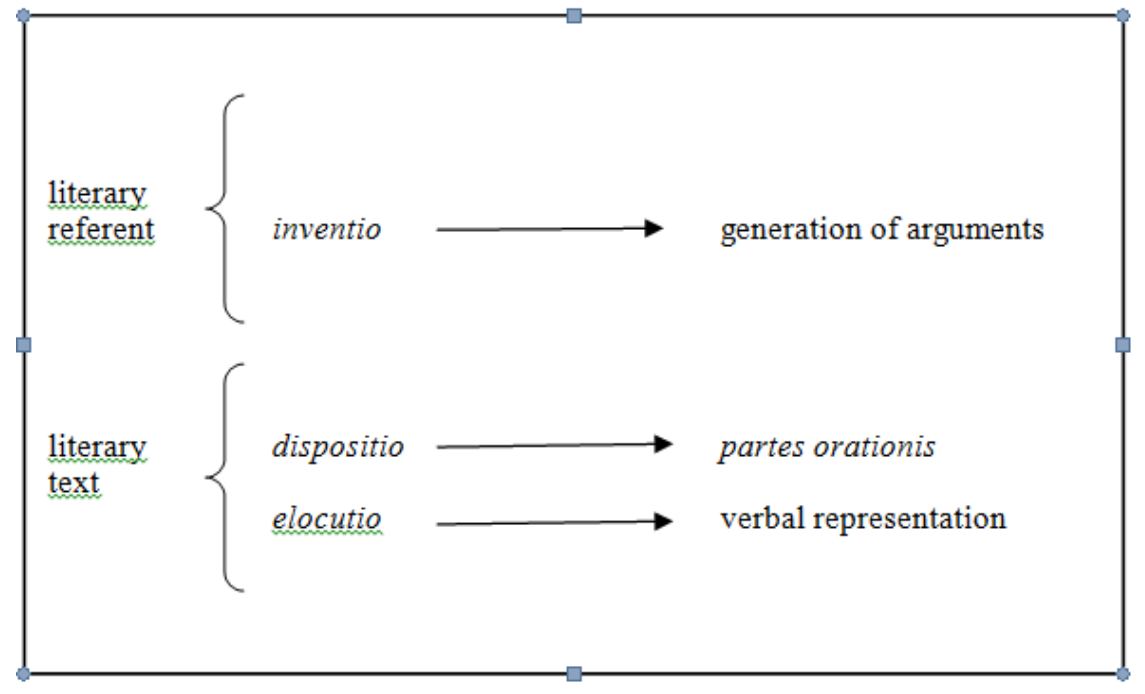

By means of elocutio, the reader recognises possible expressive devices such as rhetorical figures. The essayist, when building this elocutio level, activates the aesthetic function using ornatus. The component of implicit pleasure in the concept of elocutive ornatus is responsible for the reader's aesthetic experience and it is an important criterion for specifying the literariness of a text. In the literary essay, ornatus has a simultaneous double intention: aesthetic, due to a peculiar textual form that may cause literary specificity, and argumentative, since it can lead a reader to reflect on the way he/she thinks (Arenas, 1997: 361-362). This view of indissolubility between arguments and figures is supported by some scholars (Vickers, 1988: 314-15; Zulick, 1998; Fahnestock, 2005: 218; Plantin, 2009: 327). 
Figure 2: Diagram of the partes orationis

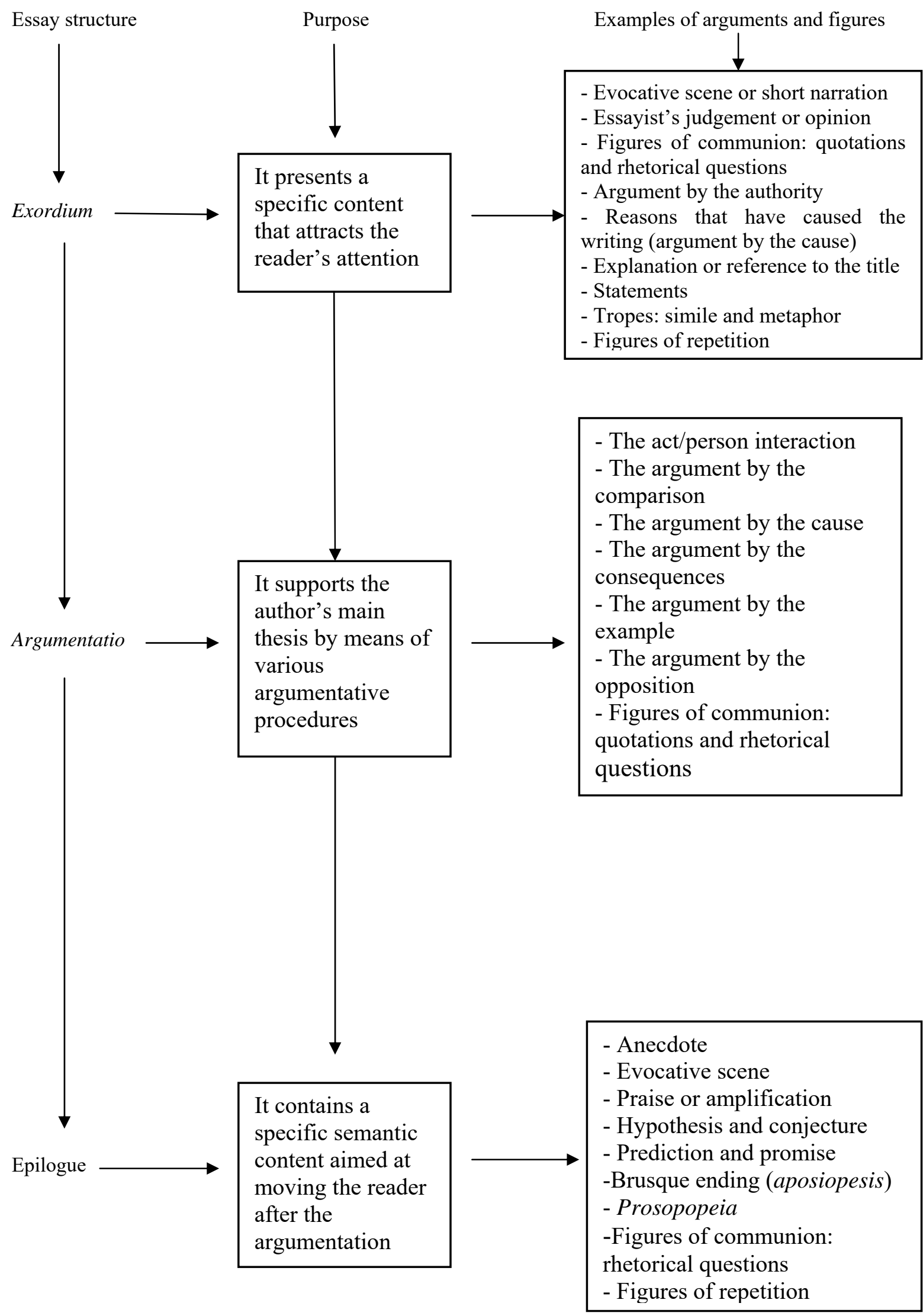




\section{Rhetorical analysis of 'Royalty'}

This essay reviews The Story of My Life by Marie, Queen of Roumania, first published in the Time and Tide newspaper, 1 December 1934. ${ }^{5}$ Apart from offering a portrait of this woman through her autobiography, Woolf introduces some criticism to the monarchy institution, as I will show with the analysis of some passages. In the essay, Woolf refers to the royal family as "lions and tigers" that are kept "in a beautiful brightly lit room behind bars". The identification of these people with caged animals involves a metaphorical process that students should recognise and evaluate. This trope will be recurrent in the text and entails an effective rhetorical device in the essay. Its presence in the levels of inuentio and dispositio is complemented by other rhetorical figures in elocutio, as I point out below in my analysis of the partes orationis.

\subsection{Exordium}

The first paragraph introduces the reasons why the essayist considers this particular review worthy of attention: "The reasons seem to be that she is royal; that she can write; that no royal person has ever been able to write before; and that the consequences may well be extremely serious".

In offering these motives, the author anticipates some of the ideas that the reader will be able to discover, like the criticism towards royalty and Marie's gentle portrait. Furthermore, the explicit mention of the noun "reason" should help the reader realise that these lines can be analysed as an argument by the cause. This argument is a semantic content typical of the exordium that tries to catch the reader's interest and predispose him/her favourably.

\subsection{Argumentatio}

This is the longest section and comprises six paragraphs. In the first one, Woolf offers a metaphorical definition of royalty that equals the regal members to wild animals that have been confined in a luxury cage for ages:

Royalty to begin with, merely as an experiment in the breeding of human nature, is of great psychological interest. For centuries a certain family has been segregated; bred with a care only lavished upon race-horses; splendidly housed, clothed, and fed; abnormally stimulated in some ways, suppressed in others; worshipped, stared at, and kept shut up, as lions and tigers are kept, in a beautiful brightly lit room behind bars.

In the second paragraph, Woolf continues using the same metaphorical elements to describe Queen Marie, the writer that she is assessing: "Now one of these royal animals, Queen Marie of Roumania, has done what had never been done before; she has opened the door of the cage and sauntered out into the street. Queen Marie can write; in a second, therefore, the bars are down." 
Readers should reflect on the criticism to the regal institution that the essayist exposes when she states that Marie can escape from her prison due to her ability to write, probably meaning that other royals cannot excel at anything so worthwhile. The development of the argument by the person/act interaction is described by means of some quotes that Woolf introduces from Marie's autobiography where she describes her grandmother, Queen Victoria:

Queen Victoria's teeth were 'small like those of a mouse'; she had a way of shrugging her shoulders when she laughed; when they rode on the sands at evening 'the shadows become so long that it is as though our horses were walking on stilts'; there was a marvellous stone in the museum, like a large piece of shortbread, that 'swayed slightly up and down when held at one end'.

Some other comments by Woolf summarise her views about these excerpts: "This little girl, in short, smelt, touched, and saw as other children do; but she had an unusual power of following her feeling until she had coined the word for it. That is to say, she can write". These observations represent an example of the interaction between Marie of Roumania and her work, of how her life affects her literary work and vice versa. The use of these attributed quotations reveals the use of a figure of communion that tries to bring about or increase communion with the audience by evoking Marie's presence throughout the text (Perelman and Olbrechts-Tyteca, 1969; Tindale, 2004; Graff and Winn, 2006).

In the third paragraph, Woolf presents an argument by the comparison to reflect the differences between Queen Victoria and Marie's writing. While the first had to write out of duty, the second could indulge in her written work: "If we want an example of the difference between writing and non-writing we have only to compare a page of Queen Marie with a page of Queen Victoria". The essayist affirms that Queen Victoria's writing "was forced by the exigencies of her profession to fill an immense number of pages, and some of these have been printed and bound between covers". In the course of her explanation, Woolf uses a simile that exposes the queen's endeavour tellingly: "She has to express herself in words; but words will not come to her call. When she feels strongly and tries to say so, it is like hearing an old savage beating with a wooden spoon on a drum". After the inclusion of more quoted examples that support her opinion about Victoria's poor writing, Woolf adds a sentence that also reinforces her negative vision of royalty as an institution that is detached from people: "The majority of her subjects, knowing her through her writing, came to feel that only a woman immune from the usual frailties and passions of human nature could write as Queen Victoria wrote. It added to her royalty".

In contrast, Victoria's granddaughter, Marie of Roumania, "has been born with a pen in her hand. Words do her bidding". This is the beginning of the fourth paragraph in which Woolf praises Marie's ability to reflect her experiences in the autobiography that she is reviewing. More extracts from the book are exposed so that readers can continue feeling Marie's presence in the essay. In the passage, Marie explains how she decided to write about herself: 
'Even as a child', she says, 'I possessed a vivid imagination and I liked telling stories to my sisters .... Then one of my children said to me: "Mama, you ought to write all this down, it is a pity to allow so many beautiful pictures to fade away" . . . I knew nothing whatever about writing, about style or composition, or about the "rules of the game", but I did know how to conjure up beauty, also at times, emotion. I also had a vast store of words.'

The essayist underlines that "she is able to hit off a moment's impression, a vivid detail" and that "she has the rarer power of sweeping these figures along in a torrent of language; lives grow and change beneath our eyes; scenes form themselves; details arrange themselves; all the actors come alive". In this example, some rhetorical figures of repetition are used to emphasise Marie' writing style through the rhythmical sequence of the sentences. The reiteration of symmetrical short sentences that are of approximately equal length and corresponding structure can be analysed as isocolon (Lanham 1991: 93). Furthermore, the repetition of the same word at the end of a sequence of clauses or sentences as in "scenes form themselves; details arrange themselves" is called epistrophe and suggests the queen's ability to create a coherent text starting from different elements (Lanham, 1991: 16).

The fifth paragraph is intent on offering some details about Marie's portrait of her royal relative Elizabeth of Roumania. The essayist provides a summary of how Marie sees this "dear charming Queen" through a narrative that includes excerpts like this one:

She becomes a complex, contradictory human being, wearing floating veils and a motoring cap, at once 'splendid and absurd'. We see her posing in bed under a top light; dramatizing herself melodramatically; luxuriating in the flattery of sycophants; declaiming poetry through a megaphone to ships at sea; waving a napkin to grazing cows whom she mistakes for loyal subjects - deluded and fantastic, but at the same time generous and sincere.

In the description of this queen's doings, Woolf uses several -ing verbs that denote action and grant the passage a dynamic quality. The repetition of similar endings to words, phrases or sentences can be analysed as homoioteleuton (Lanham, 1991: 83-85). Although this section of the essay is entirely devoted to the description of this grand character, the reader should be reminded that Woolf still continues to show more evidence of how Marie's work can contribute to characterising her personality by using the act/person interaction.

The sixth paragraph introduces Woolf's consideration that "nobody is going to claim that Queen Marie ranks with Saint Simon or with Proust". But maybe this lesser compliment is replaced by her next remark that extends the opening metaphor that likens Marie to caged animals, by means of which "it would be equally absurd to deny that by virtue of her pen she has won her freedom". As a result of this liberation, "She is no longer a royal queen in a cage. She ranges the world, free like any other human being to laugh, to scold, to say what she likes, to be what she is. And if she has escaped, so too, thanks to her, have we. Royalty is no longer quite royal."

This extract contains more rhetorical figures of repetition. Firstly, the isocolon that underscores the queen's "newly" mundane activities by the reiteration of several 
infinitive verbs: "free like any other human being to laugh, to scold, to say what she likes, to be what she is". Secondly, through polyptoton, which repeats a word in a different form in the negative statement "Royalty is no longer royal". In polyptoton, a change of form and a change of function occur at the same time (Fahnestock, 1999: 168-177; 2011: 30). The lexeme "royalty" appears first as a noun and then as an adjective in "royal". In this example the negation that is present in the predicate deprives the term "royalty" of all its otherworldly qualities and, as a result, it is "no longer royal". Thirdly, the isocolon that, once more, stresses the rhythmical movements of Marie's relatives as if they were puppets, which supports her unfavourable image of monarchy: "Uncle Bertie, Onkel, Aunty, Nando, and the rest are not mere effigies bowing and smiling, opening bazaars, expressing exalted sentiments, and remembering faces always with the same sweet smile". And, finally, the same figure is used to define them as "violent and eccentric; charming and ill-tempered; some have bloodshot eyes; others handle flowers with a peculiar tenderness. In short, they are very like ourselves. They live as we do".

\subsection{Epilogue}

The final paragraph contains several rhetorical questions that can make the reader ponder about the future of monarchy and, at the same time, they can be interpreted as an irony that questions the value of the longstanding institution. The rhetorical question is a figure of communion that also tries to empathise with the audience. It does not try to provoke an immediate answer even if the author obtains the audience's agreement. It is not a real question, but a statement intoned or punctuated as a question (Fahnestock, 2011: 298-299). In the essays selected, this procedure involves series of reflections on Woolf's part about, in the first place, the utility of the institution and the respect that we must owe to people that seem to be like us:

But what will be the consequences if this familiarity between them and us increases? Can we go on bowing and curtseying to people who are just like ourselves? Are we not already a little ashamed of the pushing and the staring now that we know from these two stout volumes that one at least of the animals can talk?

In the second place, another set of questions hints at the possibility of Marie's gift being inherited by her descendants. Consequently, monarchy may lose its strength if their members start to have talents of their own or if we start to realise that they are more than living statues who salute and whom we salute:

[...] and if Queen Marie's descendants improve upon her gift as much as she has improved upon Queen Victoria's is it not quite possible that a real poet will be King of England in a hundred years' time? And suppose that among the autumn books of 2034 is Prometheus Unbound, by George the Sixth, or Wuthering Heights, by Elizabeth the Second, what will be the effect upon their loyal subjects? Will the British Empire survive? Will Buckingham Palace look as solid then as it does now? 
These rhetorical questions pose at the same time a hypothesis about the future literary accomplishments of some royal members and the citizens' new views towards the institution if this happens. The two final sentences suggest a change of mind deriving from this fateful prediction that can place monarchy in jeopardy: "Words are dangerous things, let us remember. A republic might be brought into being by a poem". The use of both rhetorical questions and hypotheses is a semantic content representative of the epilogue as regards to obtaining the reader's good disposition even in the last lines of the text and making them reflect on the ideas exposed.

\section{Discussion and conclusions}

After the analysis, readers can examine the form of the essay and recognise the partes orationis but, are they capable of saying why the text is persuasive, or even emotive, it that is case? Can they, in brief, describe the style of 'Royalty'? In this respect, style is more than choosing certain word forms and recognising some rhetorical figures. Style has to do with the conjunction of all the elements encountered at the levels of inuentio, dispositio and elocutio (Gross and Dearin, 2003: 135). Students should then assess how the choice of specific structures helps to transmit a certain thought and whether this thought is significant in the text.

In the case of 'Royalty', the reader can make the following account of single effects that are meant to acquire a global meaning and, as a result, produce expressive force in the essay:

1. At the level of inuentio, the person/act interaction is the main argument that allows Woolf her particular review of Marie's work.

2. In arrangement or dispositio, a specific ordering of arguments and rhetorical figures is followed:

a. Exordium: the reader has identified an argument by the cause as the main semantic content that tries to attract the reader's good favour. Furthermore, the causes exposed point at an allegedly negative conception of monarchy.

b. Argumentatio: the reader has recognised several arguments and figures in order to sustain a definite image of the character that is being portrayed:

i. The metaphor that identifies the members of the royal family with wild animals imprisoned in a cage. This metaphor is extended and appears in several fragments of the essay.

ii. Quotes from Marie's autobiography that represent figures of communion with the audience.

iii. Comments by the essayist starting from those quotes that redefine Queen Marie.

iv. An argument by the comparison between Marie and her grandmother, Queen Victoria.

v. A simile that shows Queen Victoria's poor use of words. 
vi. Figures of repetition like isocolon and epistrophe in order to emphasise Marie's talent with words; homoioteleuton, in order to describe some of Marie's family portraits, and polyptoton, in order to criticise the notion of royalty.

c. Epilogue: the reader has distinguished the inclusion of rhetorical questions as figures of communion that can be interpreted as ironical pleas as to the future of royalty, and hypotheses about the achievements of their members. Both the questions and the hypotheses are regarded as semantic contents of the epilogue.

This sequence of arguments and figures in arrangement or dispositio can become persuasive if the students are trained to perceive the following conditions (Gross and Dearing, 2003: 99-113):

- The logical order of arguments into exordium, argumentatio and epilogue.

- The psychological order of arguments by means of which the essayist redefines Marie as a vivid and charming character that does not live in an inaccessible palace like some of her other royal relatives. As a result, Marie is presented as a gentle person through the unfolding of quotes from her autobiography and the essayist's positive comments.

- The self-referential nature of Woolf's essay that is related with the audience's consciousness of a specific arrangement. In particular, Woolf's readers of this and other essays will look for an introduction, a development of ideas and a conclusion in those texts concerned with the review of an author and/or his/her work, and this arrangement can favour their receptivity.

3. In elocutio or style, a set of arguments and rhetorical figures is offered throughout the partes orationis:

a. The initial argument by the cause that gives the reasons for writing the essay.

b. Metaphor and simile are tropes used for different purposes: the first figure offers a novel way of presenting royalty, and the second describes the queen Victoria's writing habits.

c. The quotes from Marie's autobiography and the rhetorical questions are interpreted as figures of communion with readers.

d. Some figures of repetition are inserted in argumentatio to underline several notions. The figures examined are isocolon, epistrophe, homoioteleuton and polyptoton.

In relation to other Woolf's essays, a close reading of her literary reviews confirms that she usually keeps the same order: she starts by offering an introductory argument to attract her readers' good favour and present the character and/or the work that she is talking about. Then she develops the argumentation by means of the act/person 
interaction, offering quotes from the work that she is reviewing as well and anecdotes and personal details of the character under discussion that can bring him/her to presence. Finally, she concludes with reasonings that are also representative of the epilogue.

Once readers have identified and interpreted the group of arguments and rhetorical figures, they can finally try to explain why 'Royalty' is emotive or expressive. They should conclude that, bearing in mind all the devices analysed above at the levels of inuentio, dispositio and elocutio, Woolf presents Marie of Roumania as a capable writer who could escape from her royal prison due to her way with words, as reflected by metaphor; who became a freer person because of this literary talent, as remarked by several figures of repetition; and who could enjoy life as she wished, as read in the quotations from her autobiography and the essayist's further comments. Hence, Marie's final image as a remarkable woman who could do as she wished despite her royal condition is the result of the conjunction of all these rhetorical elements.

\subsection{Some guidelines for the analysis}

My purpose with this article has been to offer a model of analysis that can be applied not only to Woolf's essays but also to other authors', with the subsequent variations in their nonfiction work. The rhetorical approach is especially apt for the reading and interpretation of the argumentative discourse, and allows both the identification of partes artis, which requires some knowledge of the author's context pertaining to the motivations for his/her essay writing at the level of inuentio, and the partes orationis that are found in dispositio.

I include below a list of questions that may be used as training for approaching the essay from a rhetorical perspective. These questions can be adapted to essays dealing with topics that do not necessarily include the review of an author or his/her work. However, the recognition of partes artis and partes orationis should be possible in those essays that contain an argumentative nature.

- Which is the main argument generated by inuentio?

- Can you identify all the partes orationis? Which arguments are prevalent in each category?

- Do the partes orationis follow a logical order into introduction, narration/exposition, argumentation and epilogue?

- How can arrangement or dispositio become persuasive? Which conditions should be recognised?

- Which rhetorical figures can you distinguish at the level of elocutio?

- Are these rhetorical arguments and figures intended for giving a positive or a negative image of the theme/character/work under consideration? Can you give some examples that hint at one or the other possibility?

- Would you say that these devices contribute to praising the character/work that is being reviewed? If the answer is affirmative/negative, in which way does the essayist achieve that? 
- After enumerating all the arguments and figures that you have previously identified, can you explain in which way they help to define the expressive or emotive force of the essay? Which final image do you perceive of the theme/character/work reviewed?

\section{Notes}

1. Some studies on the style of the essay are "James Baldwin's Style: A Prospectus for the Classroom", by J. F. Fleischauer (1975), “Shooting an Elephant' - An Essay to Teach”, by K. Keskinen (1966), and "On the Neglect of Twentieth-Century Nonfiction: A Writing Teacher's View”, by D. Rygiel (1984).

2. For a recent treatment of critical studies on Woolf's essay writing, see Leila Brosnan (1997), Reading Virginia Woolf's Essays and Journalism. Breaking the Surface of Silence. Edinburgh: Edinburgh University Press; Beth Carole Rosenberg and Jeanne Dubino (Eds.) (1997), Virginia Woolf and the Essay. New York: St. Martin's Press; Elena Gualtieri (2000), Virginia Woolf's Essays: Sketching the Past. London: Macmillan; Anne Fernald (2006), Virginia Woolf. Feminism and the Reader. New York: Palgrave Macmillan; Judith Allen (2010), Virginia Woolf and the Politics of Language. Edinburgh: Edinburgh University Press; Randi Saloman (2012), Virginia Woolf's Essayism. Edinburgh: Edinburgh University Press.

3. See Virginia Woolf (1984). The Common Reader. First Series. New York: Harcourt Brace.

4. In Rhetorica ad Herennium the following partes orationis are discussed: exordium or introduction, narratio or statement of facts, divisio or division, confirmatio or proof, confutatio or refutation, and conclusio or conclusion ([Cicero] 1981: I.3). Quintilian distinguishes five main partes orationis: proemium or introduction, statement of facts, proof, refutation and peroration (Quintilian 1920: III.8).

5. The text was then reprinted in The Moment and Other Essays (1947), edited by the Hogarth Press; in the fourth volume of Collected Essays (1967) also edited by the Hogarth Press; in the anthology Women and Writing, edited by Michèle Barrett in 1979; the anthology A Woman's Essays, edited by Rachel Bowlby in 1992, which is the one used for this study and, finally, in the sixth and last volume of The Essays of Virginia Woolf, edited by Stuart Clarke in 2011.

\section{References}

Albadalejo, Tomás (1989): Retórica. Madrid: Editorial Síntesis.

Arenas-Cruz, M. Elena (1997): Hacia una teoría general del ensayo. Construcción del texto ensayístico. Cuenca: Universidad de Castilla-La Mancha.

Aristotle (1909): The Rhetoric of Aristotle (Sir Richard Claverhouse Jebb, Trans.). Cambridge: Cambridge University Press.

Barthes, Roland (1982): Investigaciones retóricas I. La antigua retórica (B. Dorriots, Trans.). Barcelona: Ediciones Buenos Aires.

Cicero (1981): Rhetorica ad Herennium (H. Caplan, Trans.). Cambridge, MA: Harvard University Press. 
Crosswhite, James (2011): “Awakening the Topoi: Sources of Invention in The New Rhetoric's Argument Model". In John T. Cage, ed., The Promise of Reason. Studies in The New Rhetoric. Carbondale and Edwardsville: Southern Illinois University Press, 185-205.

Fahnestock, Jeanne (1999): Rhetorical Figures in Science. Oxford: Oxford University Press.

Fahnestock, Jeanne (2005): Rhetorical Stylistics. Language and Literature, 14(3): 215-230.

Fahnestock, Jeanne (2011): Rhetorical Style. The Uses of Language in Persuasion. Oxford: Oxford University Press.

Fleischauer, John F. (1975): “James Baldwin's Style: A Prospectus for the Classroom”. College Composition and Communication, 26(2): 141-148.

Graff, Richard and Winn, Wendy (2006): 'Presencing 'Communion' in Chaïm Perelman's New Rhetoric". Philosophy and Rhetoric, 39(1): 45-71.

Gross, A. G. and Dearin, R. D. (2003): Chaïm Perelman. Albany: SUNY Press.

Keskinen, Kenneth (1966): “Shooting an Elephant' - An Essay to Teach". The English Journal, 55(6): 669-675.

Lanham, Richard A. (1991): A Handlist of Rhetorical Terms (2nd ed.). Berkeley and Los Angeles: University of California Press.

Lausberg, Heinrich (1983): Manual de retórica literaria. Tomo I (J. Pérez-Riesgo, Trans.). Madrid: Editorial Gredos.

Lojo-Rodríguez, Laura (2001): “'A New Tradition': Virginia Woolf and the Personal Essay”. Atlantis, 23(1): 75-90.

Perelman, Chaïm and Olbrechts-Tyteca, Lucie (1969): The New Rhetoric. A Treatise on Argumentation (J. Wilkinson and P. Weaver, Trans.). Notre Dame, IN: University of Notre Dame Press.

Plantin, Christian (2009): "A Place for Figures of Speech in Argumentation Theory". Argumentation, 23(3): 325-337.

Quintilian (1920): Institutio Oratoria, vols I-IV (H. E. Butler, Trans.). Cambridge, MA: Harvard University Press.

Rygiel, Dennis (1984): “On the Neglect of Twentieth-Century Nonfiction: A Writing Teacher's View”. College English, 46(4): 392-400.

Saloman, Randi (2012): Virginia Woolf's Essayism. Edinburgh: Edinburgh University Press.

Saloman, Randi (2013): “Unsolved Problems': Essayism, Counterfactuals, and the Futures of A Room of One's Own". Tulsa Studies in Women's Literature, 32(1): 53-73.

Sánchez-Cuervo, M. Esther (2004): La argumentación retórica en los ensayos de Virginia Woolf. Tesis doctoral. Granada: Servicio de publicaciones de la Universidad de Granada.

Sánchez-Cuervo, M. Esther (2010): “'Ah, but what is herself? I mean, what is a woman?': Rhetorical Analysis of Virginia Woolf’s Feminist Essays”. ES. Revista de Filología Inglesa, 31: 263-286.

Sánchez-Cuervo, M. Esther (2015): "Katherine Mansfield about Katherine Mansfield: Rhetorical Analysis of Virginia Woolf's 'A Terribly Sensitive Mind"”. Neophilologus, 99(2): 335-349.

Tindale, Christopher W. (2004): Rhetorical Argumentation. Thousand Oaks, CA: Sage.

Vickers, Brian (1988): In Defence of Rhetoric. Oxford: Clarendon Press.

Woolf, Virginia (1992): A Woman's Essays. Selected Essays. Volume One. R. Bowlby, ed., Harmondsworth: Penguin.

Zulick, Margaret D. (1998): "The Normative, the Proper and the Sublime: Notes on the Use of Figure and Emotion in Prophetic Argument". Argumentation, 12(4): 481-492. 